\title{
En sykepleierutdanning for fremtiden
}

Sykepleierutdanningens historie er preget av perioder med faglige brytninger. Nå skal enda en ny kurs meisles ut.

\section{Kari Brodtkorb}

Førstelektor

Institutt for helse- og sykepleievitenskap, Universitetet i Agder, Grimstad

Sykepleierutdanning

Utdanningsdebatt

Akademia

Praksis

Sykepleien 2017105 (63961) (e-63961)

DOI: 10.4220/Sykepleiens.2017.63961

\section{Hovedbudskap}

Kunnskapsdepartementet har foreslått felles rammeplan for alle helse- og sosialfaglige grunnutdanninger samt retningslinjer for hver enkelt utdanning. Det vil innebære et viktig endringsarbeid for norsk sykepleieutdanning. Artikkelen omtaler temaer som historisk sett har preget utdanningsdebatten, og som også er aktuelle i dag og i fremtiden. God utdanning blir til i spenningsfeltet mellom akademia og praksis.

I 2018 er det 150 år siden den første norske sykepleierutdanningen ble etablert ved Diakonisseanstalten i Oslo. 2018 vil også være et merkeår for 150-åringen. I det året starter arbeidet med å meisle ut ny kurs for utdanningen.

Norsk sykepleierutdanning er i dag rammeplanstyrt. Det innebærer at sentrale beslutningsmyndigheter utvikler en nasjonal plan som styringsverkt $\varnothing \mathrm{y}$ for det mer detaljerte planarbeidet ved den enkelte undervisningsinstitusjonen. Denne ordningen vil nå opphøre. 
Kunnskapsdepartementet har besluttet å avvikle de utdanningsspesifikke rammeplanene for de helse- og sosialfaglige grunnutdanningene og erstatte dem med en felles rammeplan. Det skal deretter utarbeides retningslinjer for hver enkelt utdanning.

Det gjenstår å se hva denne endringen innebærer for bachelorutdanningen $\mathrm{i}$ sykepleie. I denne artikkelen peker jeg på noen spørsmålsstillinger som har preget utdanningsdebatten, og som har aktualitet i det endringsarbeidet som vil måtte komme.

\section{Fra yrke til fag}

Sykepleie har utviklet seg fra å være et yrke til å bli et fag, og etter hvert også en profesjonell disiplin. I dag har sykepleie i seg kjennetegn fra både håndverksfag og vitenskapelige fag. Det er vesentlig for studentene å $\varnothing v e$ opp bestemte ferdigheter, redskaper og teknikker samtidig som de skal tilegne seg en forståelse for teoretisk og abstrakt stoff.

\section{«Sykepleie har utviklet seg fra å være et yrke til å bli et fag, og etter hvert også en profesjonell disiplin.»}

Funksjonsorienterte fag som sykepleie omtales ofte som profesjonelle disipliner. Gjennom forskning og utdanning har profesjonelle disipliner en forpliktelse til å utvikle en stadig bedre praksis (1).

Mange bekymrer seg for at en $\varnothing$ kende akademisering av sykepleiefaget skal medføre at de mer praktiske sidene ved faget ikke vies tilstrekkelig oppmerksomhet. De er også urolige for at tradisjonelle verdier som omsorg og verdighet skal tape terreng.

\section{Akademisering}

Forskningskompetansen og forskningsaktiviteten har hatt en formidabel $\varnothing$ kning de siste tiårene. Det har medført at vi i dag har mer kunnskap enn noen gang tidligere, utviklet av fagets egne aktører og på fagets egne premisser.

Akademiseringen av faget skjøt for alvor fart ved at sykepleie etablerte seg innen universitetssystemet. Det medførte en akademisk tenkning og ble starten på norsk sykepleieforskning.

\section{«Mange mente at sykepleien ikke var tjent med en akademisering.»}


Denne utviklingen ble ikke bare applaudert. Mange mente at sykepleien ikke var tjent med en akademisering. Andre stilte seg kritiske til at deler av fagmiljøet tilsynelatende ukritisk lot positivistisk vitenskapsfilosofi få prege den akademiske utviklingen av faget. Det ville kunne redusere sykepleie til målbare handlinger og svekke omsorgsdimensjonen (2).

Kritikken fikk stor gjennomslagskraft og påvirket etter hvert tenkningen. Inspirasjon ble hentet fra flere hold, både fra nyere amerikanske sykepleieteoretikere og europeiske filosofer. Fra 1990-tallet fikk tradisjonelle verdier en sentral plass i utdanning og yrke. Slike verdier var knyttet til den diakonale tradisjonen, som omsorg, nestekjærlighet og barmhjertighet (3).

Parallelt $\varnothing$ kte sykepleieforskningen i omfang. I dag er den preget av et metodisk mangfold og nærhet til den kliniske sykepleien. Det bidrar til å sikre at kunnskapen har relevans der den skal brukes.

\section{Omsorgsperspektivet}

Norsk sykepleierutdanning har både sekulære og diakonale tradisjoner.

Tankegodset fra den diakonale tradisjonen har hatt et tydelig omsorgsfilosofisk preg, mens de sekulære skolene ble viktigste pådriver for å utvikle faget og styrke utdanningen (3).

Etter andre verdenskrig var medisinen på fremmarsj. Den dominerte etter hvert både sykepleiefunksjonen og utdanningen. Som en motreaksjon vokste det frem et behov for å synliggjøre sykepleiens særegne funksjon og utvikle et eget kunnskapsgrunnlag (4). Sykepleie ble mer knyttet til samfunnsfagene, og de tradisjonelle aspektene ved faget ble redusert.

Sykepleier og filosof Kari Martinsens kritiske røst mot å tone ned omsorgen (2) bidro til at omsorgsfilosofien fikk et oppsving på 1990-tallet. Men tidene endret seg. Tenkningen og debattene rundt hvilke aspekter ved faget som skal vektlegges, er en del av strømninger i helsesektoren og samfunnet for øvrig.

\section{Medisinsk-teknisk syn}

Innføring av nye $\varnothing$ konomiske styringsmodeller i helsetjenestene, basert på ideologien New Public Management (NPM), har påvirket både helsetjenestene og utdanningene (5). På ny fikk vi en reaksjon mot omsorgsfilosofien.

\section{«På ny fikk vi en reaksjon mot omsorgsfilosofien.»}


I dag er det en tydelig trend å vektlegge de medisinsk-tekniske aspektene ved faget fordi nyutdannete sykepleiere har behov for mer handlingskompetanse. Det er et $\emptyset$ nske som forsterkes i dag i takt med utviklingen innen medisinsk og annen naturvitenskapelig kunnskap.

Ønsket forsterkes også i takt med komplekse tekniske intervensjoner og mer søkelys på effektivitet og økonomiske resultater (6). Flere uttrykker bekymring for at en slik utvikling igjen kan true vesentlige omsorgsverdier $(5,7,8)$.

\section{Mer standardisering}

Vi lever i en tid der troen på og kravet om ensretting og standardisering preger stadig flere livsområder, også sykepleie. Ingunn Elstad (9) fremholder at små og store, formelle og uformelle rutiner er nødvendig sykepleiepraksis. Rutinene kan være i form av standarder, som kan være romslige eller trange, nødvendige eller overflødige.

Tanken er at arbeidet blir mer effektivt, og at kvaliteten sikres. Men når kontinuerlige praksiser stykkes for mye opp, kan det svekke flyten og oversikten.

I den senere tiden er spørsmålet om behov for mer standardisering av utdanningen blitt diskutert. Nasjonale rammeplaner kan være mer eller mindre detaljerte, slik at de enkelte læreinstitusjonene får større eller mindre fullmakter og ansvar når de skal utforme egne planer (10).

\section{NSF på kollisjonskurs}

Både Norsk Sykepleierforbund (NSF) og NSF Student har argumentert for å beholde nasjonal rammeplan som et virkemiddel for å sikre en nasjonal standard. Studentorganisasjonen er i tillegg opptatt av at utdanningene skal ha likt innhold (11).

Ifølge NSFs politiske plattform for sykepleierutdanningen er det behov for en betydelig standardisering av både teoretiske og praktiske studier i utdanningen. Videre hevder de at lik utdanning og kompetanse for studentene er en forutsetning for å sikre pasienten kvalifisert sykepleie og riktig helsehjelp (6).

NSF har vært en tydelig pådriver for nasjonal deleksamen i anatomi, fysiologi og biokjemi, som fra høsten 2017 ble innført i alle landets utdanninger. Sykepleierforbundet tar nå et betydelig skritt videre når de hevder at også sykepleiefaget og samfunnsvitenskapelige emner bør håndteres på samme måte. Her synes de å være på kollisjonskurs med både fagmiljøene og norsk utdanningspolitikk. 


\section{Hemmende rammeplan}

I en studie der forskerne gjennomførte en tekstanalyse av gjeldende rammeplan, konkluderte de med at den har en detaljstyrende tilnærming som kan virke hemmende for en fleksibel, kreativ og eksperimenterende utdanning (12).

Ifølge Gert J.J. Biesta (13) innebærer utdanning alltid en risiko ved at man begir seg ut på en reise som delvis blir til underveis. Biesta hevder at vi i dag ser en tendens til risikoaversjon i utdanningssystemene. Et $\varnothing$ nske om at utdanningsprosesser skal kunne forhåndsdefineres og strømlinjeformes, harmonerer dårlig med et læringssyn der utdanning ses som samhandling mellom mennesker.

I utdanningsmeldingen (14) heter det at utdanningskvalitet i hovedsak skapes lokalt og er kulturavhengig. Den blir til i møte mellom studenter og undervisere, mellom undervisere og mellom studenter. I meldingen antas distribuert faglig beslutningsmyndighet å være en forutsetning for å drive kvalitetsutvikling og nytenkning.

\section{Løsere bånd til sykehus}

Over tid har båndene mellom sykepleierutdanning og sykehus blitt løsere. Frem til 1948 var sykepleierutdanningen eid av sykehusene. I 1948 ble lov om utdanning og offentlig godkjenning av sykepleiere vedtatt. Loven medførte over tid $\varnothing \mathrm{kt}$ anerkjennelse av sykepleiere og vekst av sykepleie som profesjon.

\section{«Over tid har båndene mellom sykepleierutdanning og sykehus blitt løsere.»}

Egne sykepleiehøyskoler ble etablert på 1970-tallet. Skolene ble overført fra Sosialdepartementet til Kirke- og undervisningsdepartementet i 1981, og universiteter og høyskoler fikk felles lovverk på 1990-tallet. Det bidro til ytterligere løsrivelse (15).

I tiden som kommer vil kommunehelsetjenesten bli en stadig viktigere samarbeidspart for utdanningene. Samhandlingsreformens målsetting om mer sammenhengende og helhetlige pasientforløp og en styrket kommunal helse- og omsorgstjeneste medfører en mer omfattende sykepleiefunksjon med nye krav til kompetanse (16).

Utdanningsinstitusjonene må bidra til denne utviklingen ved å rette seg mer mot kommunehelsetjenesten, særlig i de praktiske studiene. I dag omstilles og effektiviseres sykehusene, og det skaper et press på veiledningsressurser og læresituasjoner. 
Tiden er moden for en vektforskyvning mot de kommunale tjenestene når det gjelder praksisstudier. Imidlertid er de detaljerte kravene i nåværende rammeplan til hinder for en slik vektforskyvning. Det vil også være vesentlig å sikre at kommunehelsetjenesten og spesialisthelsetjenesten likestilles når det gjelder juridisk forpliktelse til å veilede sykepleierstudenter (6).

\section{Skoletradisjon}

Hva innebærer det å drive sykepleierutdanning i universitets- og høyskolesektoren? Tilpasser man seg en tradisjonell universitetskultur, der forelesningen er den dominerende og mest statuspregete undervisningsformen? Eller bestreber man seg på å beholde undervisnings- og veiledningsformer som har lang tradisjon $\mathrm{i}$ sykepleierutdanningen?

Slike undervisnings- og veiledningsformer er mer studentaktive og ligger nærmere den kliniske virkeligheten studentene utdannes til å ta del i. Utdanningen kvalifiserer til et bestemt yrke med spesifikke og vitale funksjoner i samfunnet. Da er det nødvendig å forene trekk ved tidligere tiders skoletradisjon med dagens krav til akademiske utdanninger.

\section{Praksisintensiv}

I de senere årene har utdanningsinstitusjoner utviklet og tatt i bruk ulike digitale verktøy og lovende metoder som simulering. Slike undervisningsformer krever betydelig planlegging, koordinering og samarbeid undervisere imellom. Kontakten mellom lærer og student blir også tettere, med større muligheter for tilbakemelding, noe studentene etterlyser.

Det er i tråd med nyere utdanningspolitiske signaler om å vektlegge aktivitet og refleksjon i møte mellom studenter og undervisere og unngå at studentene blir passive mottakere av kunnskap. Utdanningsmeldingen som kom i 2016 (17), har som grunnleggende premiss at læring foregår i fellesskap, og at varierte og studentaktive lærings- og undervisningsformer i større grad bør prege høyere utdanning.

\section{«Sykepleierutdanningen er, med 50 prosent praktiske studier, den mest praksisintensive utdanningen av helsefagene.»}

Det er kostnadskrevende å drive gode teori-praksis-integrerte profesjonsutdanninger i tett relasjon til yrkesfeltet. Dessuten er sykepleierutdanningen, med 50 prosent praktiske studier, den mest praksisintensive utdanningen av helsefagene. 
Sykepleierutdanningen har et stort antall studenter og relativt god gjennomstrømming. Dermed er den en viktig inntektskilde for utdanningsinstitusjonene. Det er rimelig at en større del av denne inntekten bør tilfalle utdanningen dersom kvalitetens skal sikres.

\section{Ny kurs}

I løpet av de nærmeste årene skal en ny kurs for norsk sykepleierutdanning meisles ut. Mulighetene og utfordringene er mange. Utdanningshistorien er preget av perioder med faglige brytninger, men alltid av en ambisjon om å bidra til å utvikle gode tjenester til det beste for pasientene, de pårørende og samfunnet.

Sykepleierutdanningen er og bør være basert på en helhet av teoretisk kunnskap, yrkesspesifikke ferdigheter og faglige verdier. Sykepleie er i dag langt på vei en profesjonell disiplin. Sykepleiere utvikler i stadig større grad kunnskap på fagets egne premisser og i samarbeid med akademikere og klinikere.

Utdanningsmiljøene er godt rustet faglig og pedagogisk til å ivareta og videreutvikle kvalitet i utdanningen av sykepleiere. Viktige forutsetninger for den videre kvalitetsutviklingen er et tett og godt samarbeid mellom utdanningsinstitusjonene og praksisfeltet og bedre økonomiske rammevilkår. Det vil også være helt nødvendig med en vektforskyvning mot de kommunale tjenestene.

\section{Referanser}

1. Fagermoen MS. Sykepleie i teori og praksis - et fagdidaktisk perspektiv. Oslo: Universitetsforlaget; 1993.

2. Martinsen K. Omsorg, sykepleie og medisin. Historisk-filosofiske essays. Oslo: TANO; 2003 .

3. Tveit B. Ny ungdom i gammelt yrke - en studie av sykepleiestudenters motivasjon og fagidentitet i møte med en tradisjonsrik utdanning. Avhandling nr. 1 for ph.d.- graden i profesjonsstudier. Senter for profesjonsstudier. Oslo: Høgskolen i Oslo; 2008.

4. Kirkevold M. Vitenskap for praksis? Oslo: Ad Notam Gyldendal; 1996.

5. Aasland D. Fra mål til mening. Ord og virkelighet i profesjonell hjelp. Oslo: Gyldendal Akademisk; 2017.

6. Norsk Sykepleierforbund. Politisk plattform for sykepleieutdanning 20172020; 2016. Tilgjengelig fra: https://www.nsf.no/vis-artikkel/2187311/267816/Politiskplattform-for-sykepleierutdanning- (nedlastet 27.10.2017). 
7. Karoliussen M. Nightingales arv - ny forståelse. Sykepleiens kjerne; verdier, intensjon og handling. Oslo: Gyldendal Akademisk; 2011.

8. Hage AM. Hvem skal definere hva sykepleie er? Sykepleien 2015;103(11). Tilgjengelig fra: https://sykepleien.no/meninger/innspill/2015/11/hvem-skaldefinere-hva-sykepleie-er (nedlastet 27.10.2017).

9. Elstad I. Sjukepleietenkning. Oslo: Gyldendal Akademisk; 2014.

10. Kunnskapsdepartementet. Rammeplan for sykepleierutdanning; 2008. Tilgjengelig fra: https://www.regjeringen.no/no/dokumenter/meld.-st.-1620162017/id2536007/?q\%C2\%ADMeld (nedlastet 12.01.2018).

11. Opkvitne MA. Har vi alle det samme grunnlaget? Sykepleien 2017;105(2). Tilgjengelig fra: https://sykepleien.no/meninger/innspill/2017/O2/har-vi-alle-detsamme-grunnlaget (nedlastet 27.10.2017).

12. Solvoll B-A, Opsahl G, Granum V. Hvordan bidrar rammeplanen for norsk sykepleierutdanning til akademisk profesjonskompetanse? Uniped 2012;35(1). Tilgjengelig fra:

https://www.idunn.no/uniped/2012/O1/hvordan_bidrar_rammeplanen_for_norsk_sy kepleierutdanning_ti (nedlastet 27.10.2017).

13. Biesta GJJ. The beautiful risk of education. London: Paradigm Publishers; 2014 .

14. Meld. St. 16 (2016-2017). Kultur for kvalitet i høyere utdanning. Oslo:

Kunnskapsdepartementet; 2017. Tilgjengelig fra:

https://www.regjeringen.no/no/dokumenter/meld.-st.-16-20162017/id2536007/ (nedlastet 27.10.2017).

15. Christiansen B, Heggen K, Karseth B. Klinikk og akademia. Reformer, rammer og roller i sykepleieutdanningen. Oslo: Universitetsforlaget; 2004.

16. Meld. St. 47 (2008-2009). Samhandlingsreformen. Rett behandling - på rett sted - til rett tid. Oslo: Helse- og omsorgsdepartementet; 2009. Tilgjengelig fra: https://www.regjeringen.no/no/dokumenter/stmeld-nr-47-2008-2009-/id567201/ (nedlastet 27.10.2017).

17. Meld. St. 16 (2016-2017). Kultur for kvalitet i høyere utdanning. Oslo: Kunnskapsdepartementet; 2017. Tilgjengelig fra: https://www.regjeringen.no/no/dokumenter/meld.-st.-16-20162017/id2536007/ (nedlastet 27.10.2017). 
